\title{
Impact of Domestic Animals on Ecosystem Integrity of Lesotho High Altitude Peatlands
}

\author{
P.J. Du Preez ${ }^{1}$ and L.R. Brown ${ }^{2}$ \\ ${ }^{1}$ Department of Plant Sciences, University of the Free State \\ ${ }^{2}$ Applied Behavioral Ecology and Ecosystem Research Unit, University of South Africa \\ Republic of South Africa
}

\section{Introduction}

Wetlands are considered ecologically sensitive ecosystems with unique habitats for a great variety of plants species, birds, small mammals and other aquatic organisms. The term "wetland" is used to describe various habitats where the soil is wet for extended periods of the year but not necessarily permanently waterlogged (Collins, 2005). Wetlands are formed where surface water collects or where ground-water seeps to the surface for long-enough periods to sustain vegetation typically adapted or tolerant of hydric soil conditions. Thus wetlands comprise a large variety of waterlogged habitats such as bogs, estuaries, fens, floodplains, marshes, peatlands, playas (pans), seeps, springs, and swamps located on various altitudes and topographical locations.

In his book on wetlands of southern Africa, Cowan (1995) used the definition of a wetland as it is stated in Article 1.1 of the Ramsar Convention where it has been defined as: "areas of marsh, fen, peatland or water, whether natural or artificial, permanent or temporary, with water that is static or flowing, fresh, brackish or salt, including areas of marine water the depth of which at low tide does not exceed six metres". The South African National Water Act (Act 36 of 1998) defines wetlands as "land which is transitional between terrestrial and aquatic systems where the water table is usually at or near the surface or the land periodically covered with shallow water, and which in normal circumstances support or would support vegetation typically adapted to life in saturated soil".

Peatlands are unique wetland ecosystems in terms of their species composition and age. The process of peat formation is very slow which means that some of these wetlands are ancient as they have a deep peat deposit of over two metres. Peat is organic soil material with a particularly high organic content which, depending on the definition, usually has at least $20 \%$ organic carbon by weight. Peatlands are wetlands in which peat (dead plant matter) accumulates due to slow decomposition (Cronk \& Fennessy, 2001). These peatlands can be classified into two major types namely bogs and fens. The definition of a bog is, a peataccumulating wetland that has no significant water inflows or outflows and supports acidophilic mosses, particularly Sphagnum (usually acidic; $\mathrm{pH}<7$ ). A fen is a peataccumulating wetland that receives some water from surrounding mineral soil and usually supports marsh-like vegetation (usually alkaline; pH>7)( Cronk \& Fennessy, 2001; Mitch \& Gosselink, 2000). According to these definitions, the high-altitude wetlands of Lesotho are therefore incorrectly classified as bogs by Grobbelaar \& Stegman (1987), Herbst \& Roberts 
(1974a \& b), Jacot-Guillarmod (1962, 1963, 1972), Van Zinderen Bakker (1955), Van Zinderen Bakker \& Werger (1974). Intermediate types can also be found which are transitional between a bog and fen and a couple of defining parameters such as $\mathrm{pH} /$ alkalinity, hydrology, and nutrient availability as well as plant community structure are needed to distinguish accurately between a bog and fen. In view of this difficulty, Cronk \& Fennessy (2001) suggests that the term peatland should be used. For this study the Lesotho highaltitude wetlands will therefore be referred to as peatlands.

The functions and values of wetlands are well-known. Collins (2005) classifies these benefits as either direct or indirect benefits to mankind and to the environment. Direct benefits of wetlands are water supply, provision of harvestable resources, socio-cultural significance, tourism and recreation, and education and research. The indirect benefits are hydrological benefits such as water purification, sustained stream flow, flood reduction, groundwater recharge / discharge, and erosion control. Other indirect benefits are biodiversity conservation (integrity and irreplaceablility), and chemical cycling (Kotze, 1999, 2010; Kotze et al., 2008). Direct benefits include grazing, fibre for construction and handcraft production, fisheries, hunting of waterfowl and wildlife, valuable land for cultivation, and a valuable source of water (Collins, 2005). The peatlands of the Lesotho highlands deliver most of these direct and indirect goods and services to the environment.

For many years wetlands throughout the world have been regarded as "cheap land" that could be drained and used for development purposes. In South Africa many slimes dams from mines are located on wetlands or directly adjacent to these sensitive ecosystems. This has led to the destruction of natural vegetation and its associated animal species as well as its total ecosystem functioning. In many cases exotic invasive plant species such as the tree Eucalyptus spp. (blue gum), the shrub Tamarix chinensis, and the grasses Cortaderia jubata, C. selloana, and Pennisetum clandestinum, are planted in an attempt to dry up and stabilise the slimes dams. Various other developments such as housing, retail parks, and industrial areas have either completely destroyed wetland ecosystems or hugely impacted on its ecological functioning. Agriculture, damming of water, and invasion of alien plant species have also resulted in the destruction of wetland ecosystems and their functioning. Many crop fields and forest plantations have been established on wetlands thereby displacing the natural vegetation and animal species. The mining of peat for commercial purposes has also degraded a large number of these sensitive ecosystems.

Whereas the wetlands in South Africa are threatened by a number of human activities the wetlands of Lesotho are mostly threatened by agricultural activities such as grazing. The riverheads of the Senqu River System are situated in the Maluti Mountains of the Lesotho Kingdom where they all have their sources in high-altitude peatlands. The functioning of these high-altitude peatlands can be negatively affected by human activities. The peatlands of the Lesotho highlands are under serious threat of human activities. Jacot-Guillarmod already mentioned in 1969 that the Lesotho wetlands are under threat of degradation due to over-utilisation. The land of Lesotho belongs to the people of Lesotho, meaning that all pastoral land is held communally. Everyone has the right to use the land and its products. The land use in the upper catchments is pastoral. The land is subdivided into areas "owned" by a ward chief who may delegate his power to subordinate chiefs or headmen. Control over the numbers of domestic animals and periods they graze the wetlands is almost impossible. The resultant impact on the aquatic and semi-aquatic vegetation is severe. 
Overgrazing practices and the making of animal tracks on slopes and through wetlands result in erosion, decline in the biomass production and change in the species composition of the wetlands and surrounding catchments.

Due to the sourveld nature of the high alpine vegetation of Lesotho, the wetlands of Lesotho are considered a critical grazing resource by local Basotho herdsmen, especially in summer when thousands of sheep, goats, cattle and horses can be seen grazing on the open wetlands (Figure 1). Grazing areas are communal and controlled primarily by local chiefs (Letsela et al., 2002). The livestock industry in Lesotho has long been a vital component of the economic and social structure of the country (Mpiti-Shakhane et al., 2002) and due to the open nature (unfenced) of the Lesotho wetlands it will be a challenge to alter this over exploitation in the near future.

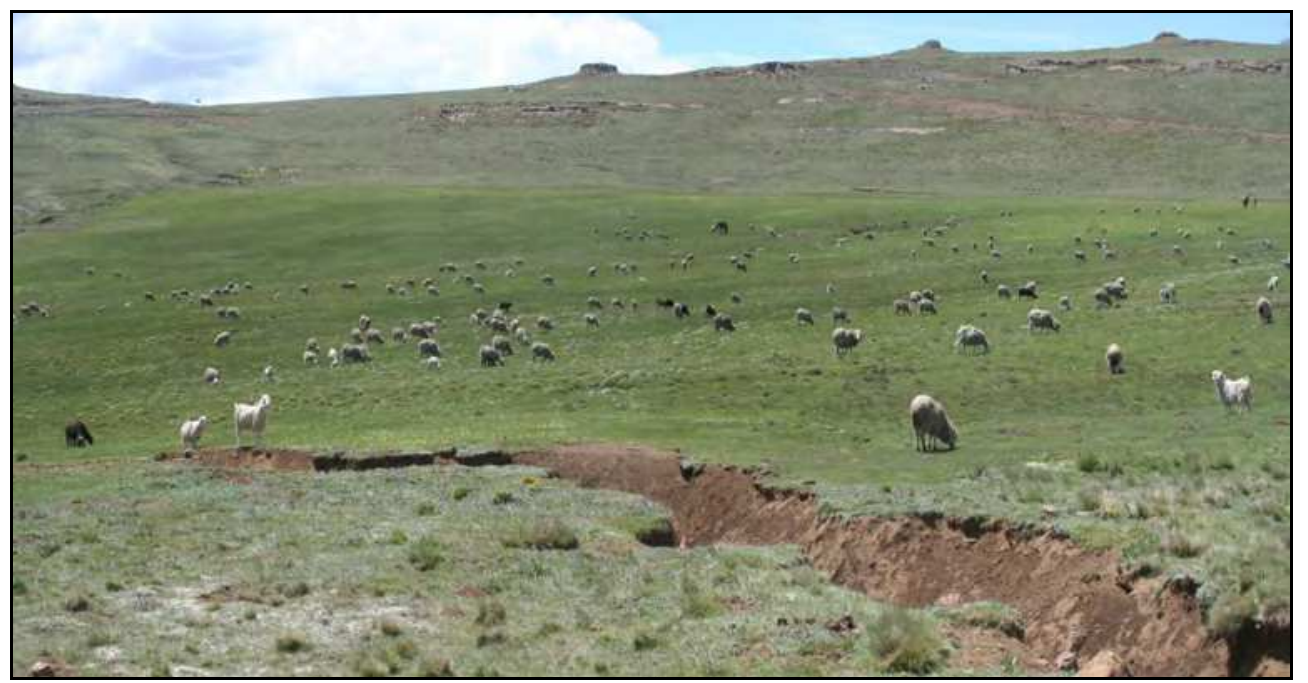

Fig. 1. Grazing of domestic animals in the high-altitude wetlands of Lesotho.

The vegetation of the study area falls within the Lesotho Highland Basalt Grassland (Gd 8) as described by Mucina \& Rutherford (2006). Although this vegetation type is one of the most endemic-rich vegetation units in the Drakensberg Alpine Centre, only $1 \%$ of it is statutorily conserved. Except for the Sehlabathebe and Bokong National Parks, the rest of the conservation areas are situated in South Africa. This implies that in Lesotho, less that $1 \%$ of the area is officially conserved. A large transfrontier park, namely the MalotiTransfrontier Park is planned to protect the high-altitude vegetation of Lesotho and South Africa. In order to determine the effect of grazing on these sensitive ecosystems this investigation was undertaken.

For this study, selected high-altitude peatlands influenced by domestic animals, were studied and compared with near pristine high-altitude peatlands in the nearby eastern Free State of South Africa. This was done by comparing the biomass production, vegetation structure and plant species composition. These comparisons allow for the assessment of the current state of these peatlands and recommendations to manage these human-impacted sensitive ecosystems in a sustainable manner. 


\section{Study area}

The study area is located on the eastern escarpment of South Africa. The South African sites are located on the Platberg plateau, while the Lesotho sites are at Khalong-la-Lithunya (Gunns pass), Koti Sepola (near Sani pass) and the Sugar bowl (Figure 2), an extinct volcano, near the Kao diamond mine. The Platberg sites are located in South Africa and above 2,300 m.a.s.l. while the Lesotho sites are all above 3,200 m.a.s.l.

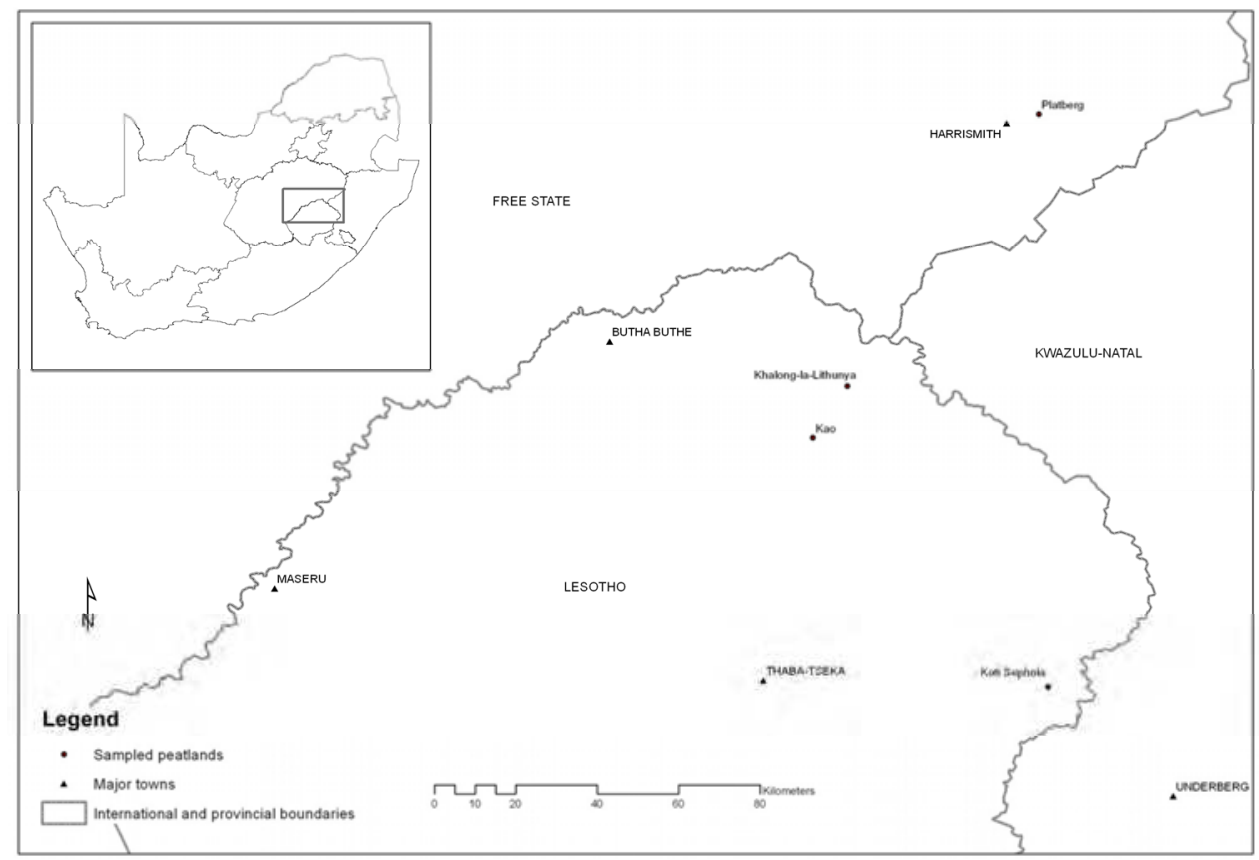

Fig. 2. Location of the study areas.

The climate is temperate cool to cold with dry winters and hot, wet summers. The climate of Lesotho is characterized by warm moist summers, from November to March; and cold dry winters from May to July. The mean monthly maximum measured at Barkley East is $31.4^{\circ} \mathrm{C}$. The rainfall is mainly in the form of thunderstorms. The mean annual precipitation (MAP) for Mokhotlong is $575 \mathrm{~mm}$. The relatively low MAP can be ascribed to a rain shadow effect. The winters are cold with frost. The mean monthly minimum measured at Barkley East is $-10.5^{\circ} \mathrm{C}$. Higher elevations above 3,000 m.a.s.l. receive enough snow during winter to cover the ground for several months with sub-freezing temperatures. On rare occasions snowfalls have been recorded in summer as well. Frost-heaving of the soil is a common phenomenon in these areas and occurs especially on barren patches. The ice crystals which are formed during frost-heaving cause the soil to lift. This kind of disturbance prevents seedlings to establish. The barren patches are therefore kept in state by the frost-heaving activities. The frost-heaving phenomenon is probably also the cause of the thufur (hummocks) which occur on peatlands (Van Zinderen Bakker \& Werger, 1974). 
As far as the geology is concerned the entire Lesotho highland is underlain by basalt of the Lesotho formation and, to a lesser extent, dolerite and gabbro. The basalt is an igneous rock that covered the Clarens Formation about 120 million years ago when Gondwana begun to breakup. Basaltic colluvium and alluvium are the geologic material for the deep soils of the mountain valleys and accumulation glacis (Schmitz \& Rooyani, 1987). The soils, at altitude, are mostly shallow and have more or less even proportions of gravel, coarse sand, fine sand, silt and clay particles. The breakdown of organic matter is a slow process due to the long periods of very low temperatures. Especially in the peatlands the accumulation of peat is the result of the decaying roots of the various plants species present on these wetlands. The peat has a high water-retention.

\section{Methods}

\subsection{Vegetation data}

A total of 18 sample plots were surveyed in the reference as well as restoration catchments of the four study sites. Plot sizes were fixed at $4 \times 4 \mathrm{~m}$ to give a total surface area of $16 \mathrm{~m}^{2}$ (Du Preez, 1991; Malan, 1998). All plant species growing in the sample plots were recorded and their cover abundance assessed using a modified Braun-Blanquet cover abundance scale (Brown, et al., 2005; Mueller-Dombois \& Ellenberg, 1974; Westhoff \& Van der Maarel, 1980).

Environmental data recorded in each sample plot included aspect, slope, exposure, the size of the rocks, latitude and longitude, altitude, locality, geology, the per cent of area covered by rock, topography, the degree of surface erosion (indicated as low moderate and severe), the degree of trampling, drainage, soil depth and notes on management and utilisation as well as total percentage canopy cover.

The habitat as well as floristic data was processed with the TURBOVEG database (Hennekens \& Schaminée, 2001). A first approximation was done with the TWINSPAN (two-way indicator-species analysis) algorithm of Hill (1979). The JUICE program (Lubomír 2002) was used to generate a phytosociological table (Table 1), which was refined by BraunBlanquet procedures.

\subsection{Biomass}

From a grazing and resilience point of view, production or yield is one of the most important measures in assessing an ecosystem (Carpenter et al., 2001). Biomass or standing crop usually refers to the weight of organisms present at one time (Pieper, 1978). Most estimates of plant biomass or standing crop include only that above the soil surfaces. This material is commonly available to large herbivores. Direct harvesting is considered the most reliable method of determining aboveground biomass (De Leeuw et al., 1991; Snyman \& Fouché, 1993). For this study two exclosure plots of $25 \mathrm{~m}^{2}$ were erected within each of the Khalong-la-Lithunya and Koti-Sephola peatland sites.

Biomass was determined in each of the exclosure and grazed plots as well in the other peatland systems by randomly placing $0.5 \mathrm{~m}^{2}$ quadrats in these areas and cutting the herbaceous material down to ground level (Figure 3). The grass and forb species were separated and dried a drying oven at $65^{\circ} \mathrm{C}$ for 48 hours (Cleaver, 2004).

The Kruskal-Wallis ANOVA by Ranks test (Welman et al., 2007) was used to compare the biomass (kilogram Dry Matter/hectare)(kg DM/ha) of the plots by grazing type while the 
the Mann-Whitney U Test (Welman et al., 2007) was used on the ranked data to determine where the pairwise differences lie.

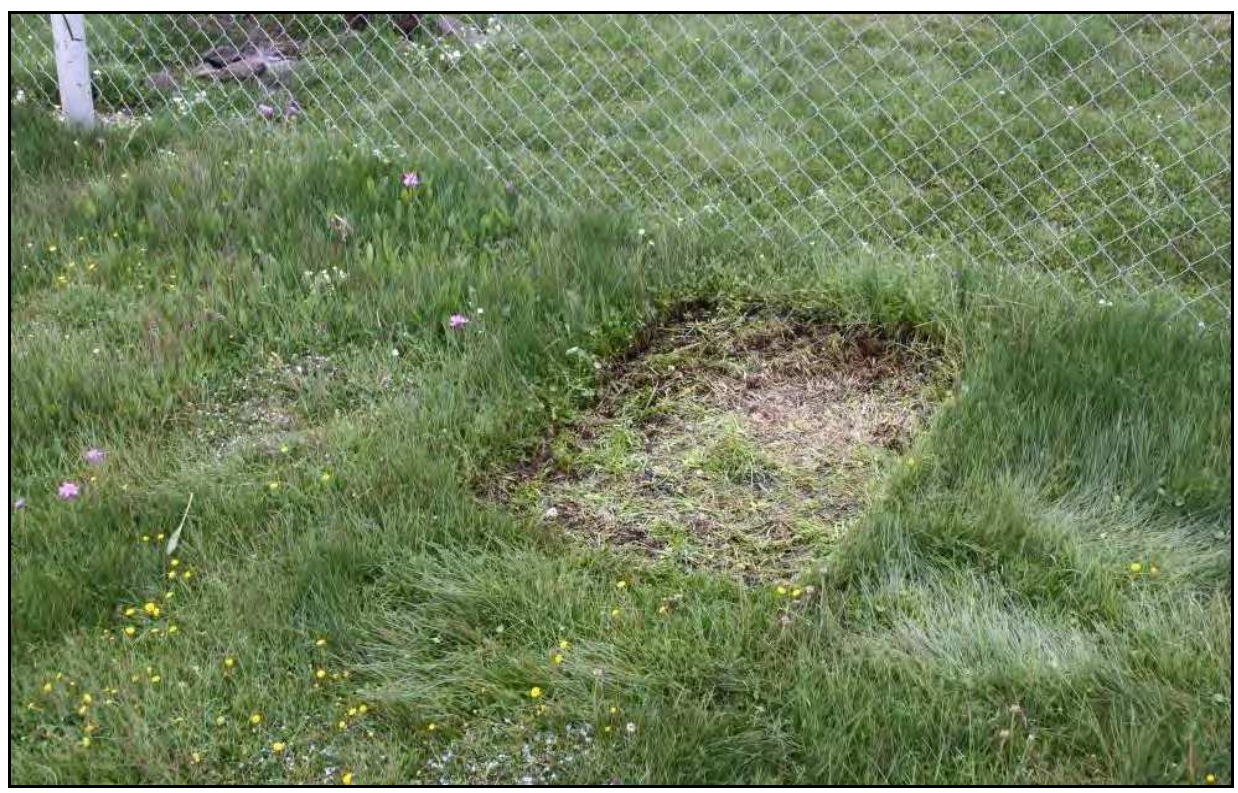

Fig. 3. All rooted herbaceous plants were harvested on a species basis in quadrats $\left(0.5 \mathrm{~m}^{2}\right)$, randomly placed in the grazed and exclosure plots in the peatlands.

\section{Results}

The analysis of the vegetation data resulted in the identification of two major plant communities namely the Pennisetum sphacelatum-Andropogon appendiculatus Peatland present on Platberg and the Haplocarpa nervosa-Isolepis cernua Peatland present on the Lesotho study sites. The phytosociological classification of the two major wetland communities is presented in Table 1.

\subsection{Khalong-la-Lithunya}

The vegetation of this peatland is dominated by the grass Pentachistis oreodoxa and the forb Haplocarpa nervosa that covers up to $75 \%$ of the area (Plots 8-11, Species group B - Table 1). The forbs Isolepis cernua, Ranunculus meyeri and Cotula radicalis are prominent throughout this community. The canopy cover of the wetland ranged between $60 \%$ and $100 \%$. A total of 21 different plant species comprising 14\% grasses and $86 \%$ forbs were identified within this wetland with the average height of the plant species ranging between 2 and $6 \mathrm{~cm}$. Small to medium sized erosion dongas were observed within this system.

In both exclosure plots the biomass was higher than that measured in the grazed plots (Figure 3). The biomass in exclosure plot 1 was $3868.4 \mathrm{~kg} \mathrm{DM} /$ ha compared to the $1020 \mathrm{~kg} \mathrm{DM} / \mathrm{ha}$ in the grazed plot 1 while the biomass of exlosure plot 2 and grazed plot 2 was $2002.7 \mathrm{~kg} \mathrm{DM} / \mathrm{ha}$ and $759.4 \mathrm{~kg} \mathrm{DM} /$ ha respectively (Figure 4). The herbaceous layer of the exclosure plots had 
an average height of $4 \mathrm{~cm}$ while the grazed plots had an average height of $2 \mathrm{~cm}$. No difference in species composition was found between the exclosure and grazed plots (Table 1).

\begin{tabular}{|c|c|c|c|c|c|c|c|c|c|c|c|c|c|c|c|c|c|c|c|c|c|}
\hline \multirow{3}{*}{ Sample plot number } & \multirow{3}{*}{, } & \multicolumn{8}{|c|}{ Platberg peatlands } & \multicolumn{3}{|c|}{1} & \multicolumn{7}{|c|}{ Lesotho peatlands } & \multirow{2}{*}{\multicolumn{2}{|c|}{$\begin{array}{r}1 \\
01\end{array}$}} \\
\hline & & 1 & 0 & 0 & 0 & 0 & 0 & 0 & 0 & & 1 & 1 & 1 & & & 1 & 1 & 11 & 10 & & \\
\hline & & I & 6 & 1 & 5 & 7 & 4 & 3 & 2 & 1 & 8 & 7 & 1 & 4 & 5 & 2 & 6 & 30 & 8 & 9 & 1 \\
\hline & & 1 & & & & & & & & 1 & & & & & & & & & & & 1 \\
\hline \multirow[t]{2}{*}{ Number of species/plot } & & 1 & o & 1 & 0 & 1 & 1 & 0 & 1 & 1 & 1 & 1 & 2 & 1 & 1 & 1 & 1 & 11 & 11 & 1 & \\
\hline & & I & 8 & 8 & 7 & 2 & 2 & 8 & 5 & 1 & 4 & 8 & 0 & 7 & 8 & 8 & 7 & $6 s$ & 99 & 6 & 1 \\
\hline Species group A: & & 1 & & & & & & & & 1 & & & & & & & & & & & I \\
\hline Andropogon appendiculatus & Grass & 1 & 5 & 1 & 1 & 1 & 1 & 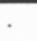 & & & . & . & . & . & . & . & . . & . . & . & & 1 \\
\hline Pennisetum sphacelatum & Grass & 1 & & + & 2 & 1 & 4 & . & 1 & 1 & $\cdot$ & . & . & . & . & . & . . & . . & . & . & 1 \\
\hline Denekia capensis & Forb & 1 & $r$ & r & $r$ & $\cdot$ & $\mathrm{r}$ & $r$ & + & I & . & . & . & $\cdot$ & $\cdot$ & . & & . . & . & . & 1 \\
\hline Senecio isatideus & Forb & 1 & + & r & & + & $r$ & . & + & I & & . & . & . & . & . & . & . . & . & . & 1 \\
\hline Geranium multisectum & Forb & 1 & & 1 & · & 1 & . & . & $\cdot$ & I & & . & . & . & . & . & · & . . & . & . & 1 \\
\hline Watsonia lepida & Geophyte & 1 & $r$ & + & + & + & . & . & . & I & - & . & . & . & . & . & • & . . & · & . & 1 \\
\hline Pentaschistis species & Grass & 1 & & + & 5 & . & 2 & $\cdot$ & 1 & I & . & . & . & . & . & . & . & ·. & . & . & 1 \\
\hline Fingerhuthia sessleriiformis & Grass & 1 & 2 & . & . & . & 3 & 1 & $\cdot$ & I & - & . & . & . & . & . & · & . . & & . & 1 \\
\hline Ficinia stolonifera & Sedge & 1 & & + & . & 5 & 2 & 5 & 1 & 1 & + & $r$ & . & . & . & . & . & . . & · & · & 1 \\
\hline Agrostis barbuligera & Grass & 1 & & & . & 1 & 1 & 1 & + & I & . & . & . & . & . & . & . & . . & . & . & 1 \\
\hline Helictotrichon longifolium & Grass & 1 & & 2 & . & + & 2 & + & 4 & 1 & - & . & . & . & . & . & . & . . & . & . & 1 \\
\hline Epilobium salignum & Forb & 1 & & + & . & $r$ & $r$ & + & + & 1 & - & . & . & . & . & . & · & . . & · & $\cdot$ & 1 \\
\hline Eriosema salignum & Forb & 1 & & $r$ & . & $r$ & r & . & $r$ & 1 & . & . & . & . & . & . & . & . . & · & . & I \\
\hline Lobelia flaccida & Forb & 1 & & + & . & $\cdot$ & $r$ & + & + & 1 & - & . & . & . & . & . & . & . . & . & . & I \\
\hline Carex species & Sedge & 1 & & + & . & . & . & . & + & I & - & . & . & . & . & & . & . . & . & . & I \\
\hline *Bromus catharticus & Grass & 1 & & + & . & . & . & . & + & I & . & . & . & . & . & . & . & . . & . & $\cdot$ & I \\
\hline Bromus firmior & Grass & 1 & L & 4 & & . & . & - & 2 & 1 & . & . & . & . & . & & . & . . & & . & I \\
\hline \multicolumn{22}{|l|}{ Species group B: } \\
\hline Isolepis cernua & Sedge & 1 & . & . & . & . & . & . & . & 1 & 2 & 2 & 3 & 3 & 3 & 2 & 1 & 22 & 25 & 55 & I \\
\hline Haplocarpha nervosa & Forb & 1 & . & . & . & . & . & . & . & I & 2 & 3 & 5 & 3 & 2 & 1 & 2 & 45 & 52 & & 1 \\
\hline Pentaschistis oreodoxa & Grass & 1 & . & . & . & $\cdot$ & . & $\cdot$ & . & I & + & 1 & 4 & 4 & 1 & 5 & + & +4 & 45 & 5 & 1 \\
\hline Cotula radicalis & Forb & 1 & . & . & . & . & . & . & . & 1 & 4 & 2 & 4 & 1 & 1 & 3 & 1 & 11 & 11 & 1 & I \\
\hline Ranunculus meyeri & Forb & 1 & . & . & . & . & . & . & . & 1 & 1 & 1 & 1 & 1 & 1 & & + & $3+$ & + & 1 & 1 \\
\hline Rhodohypoxis deflexa & Geophyte & 1 & . & . & . & . & . & . & . & I & 1 & & + & + & + & & & ++ & 1 & $1+$ & I \\
\hline Limosella longiflora & Forb & 1 & . & . & . & . & . & . & . & 1 & + & & $1+$ & & . & & + & $1+$ & + & + & 1 \\
\hline Limosella vesiculosa & Forb & 1 & . & . & . & $\cdot$ & . & . & . & 1 & + & & + & + & . & + & + & $1+$ & + & + & I \\
\hline Athrixia fontana & Forb & 1 & . & . & $\cdot$ & $\cdot$ & . & $\cdot$ & . & 1 & & $1+$ & + & + & $r$ & & + & $1+$ & & + & I \\
\hline Cerastium arabidis & Forb & 1 & . & . & . & $\cdot$ & . & . & . & I & & + & + & + & + & + & $\mathbf{r}$ & ++ & + & 1 & 1 \\
\hline Craterocapsa tarsodes & Forb & 1 & . & . & . & . & . & . & . & 1 & + & & $1+$ & + & + & . & + & . + & + & + & I \\
\hline Lobelia galpinii & Forb & 1 & . & . & . & . & . & . & . & 1 & + & & $r$ & + & $r$ & + & + & + . & + & + & I \\
\hline Dimorphotheca jucunda & Forb & 1 & . & . & . & . & . & . & . & I & r & $\mathrm{r}$ & 1 & . & $r$ & + & + & $r+$ & ++ & . & I \\
\hline Poa binnata & Grass & 1 & . & . & . & . & . & . & $\cdot$ & I & & + & + & + & + & + & $r$ & ++ & ++ & . & I \\
\hline Helichrysum bellidiastrum & Forb & 1 & . & . & . & . & . & . & . & I & & . & + & . & $r$ & + & + & + & 1 & 1. & I \\
\hline Anthoxanthum eckloniana & Grass & 1 & . & . & . & . & . & . & . & 1 & & . & + & . & . & $r$ & . & $\cdot$ & 2 & 12 & 1 \\
\hline Saniella verna & Geophyte & 1 & . & . & . & $\cdot$ & . & $\cdot$ & . & 1 & & . & $r$ & $r$ & $r$ & . & . & . + & ++ & + & I \\
\hline Wurmbia burttii & Geophyte & 1 & . & . & . & . & . & . & . & 1 & & . & $\mathrm{r}$ & $r$ & $\mathrm{r}$ & $\cdot$ & . &.+ & $+r$ & + & I \\
\hline Crassula peploides & Succulent & 1 & . & . & . & . & . & . & . & 1 & & + & . & + & + & + & + & $+r$ & $r$. & . & J \\
\hline \multicolumn{22}{|l|}{ Species group C: } \\
\hline Ranunculus multifidus & Forb & 1 & & $r$ & & + & . & $r$ & $r$ & I & & - & 1 & + & + & + & & . . & · & . & 1 \\
\hline Trifolium burchellianum & Forb & I & $r$ & + & . & + & . & . & . & I & & + & & . & + & + & & & + & $1+$ & \\
\hline
\end{tabular}

Table 1. Phytosociological table of the major high-altitude wetlands of Lesotho and Platberg. 


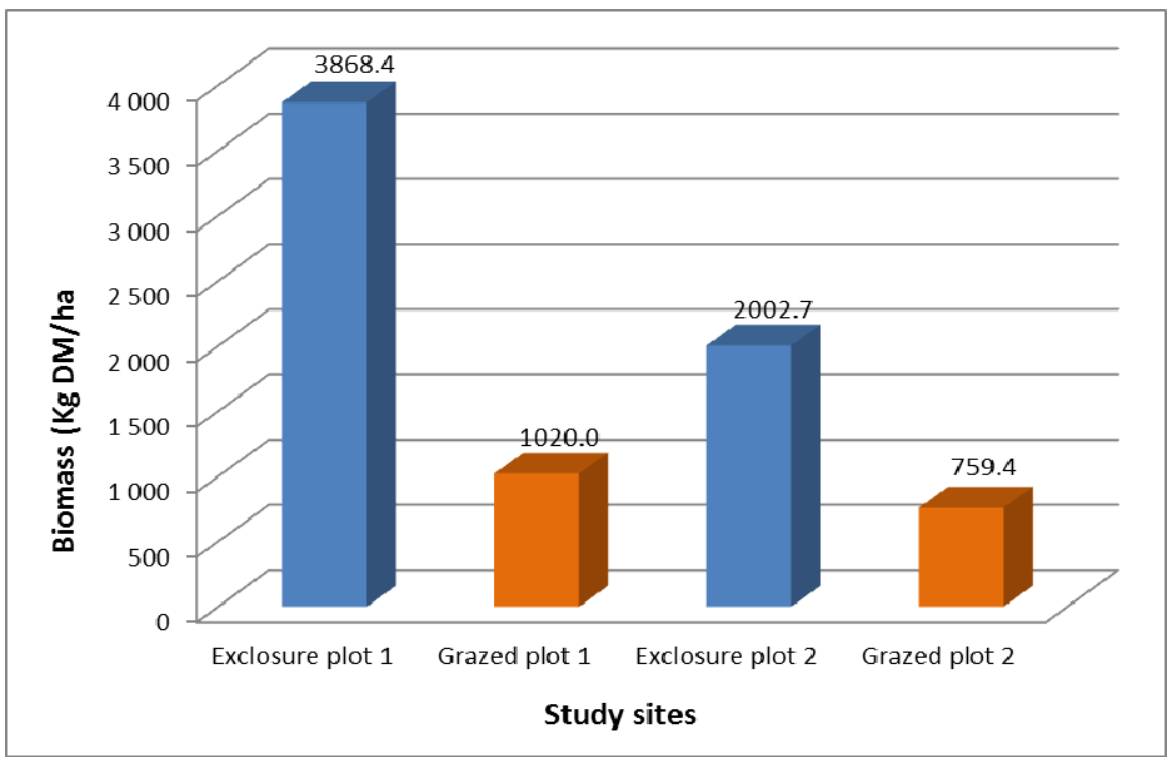

Fig. 4. Biomass of the Khalong-la-Lithunya peatland in Lesotho.

\subsection{Koti-Sephola}

The grass Pentachistis oreodoxa and the forbs Isolepis cernua, Haplocarpa nervosa dominate the vegetation each covering between $25 \%$ and $65 \%$ of the area, while the forbs Ranunculus meyeri and Cotula radicalis are also prominent (Plots 12-15, Species group B - Table 1). A total

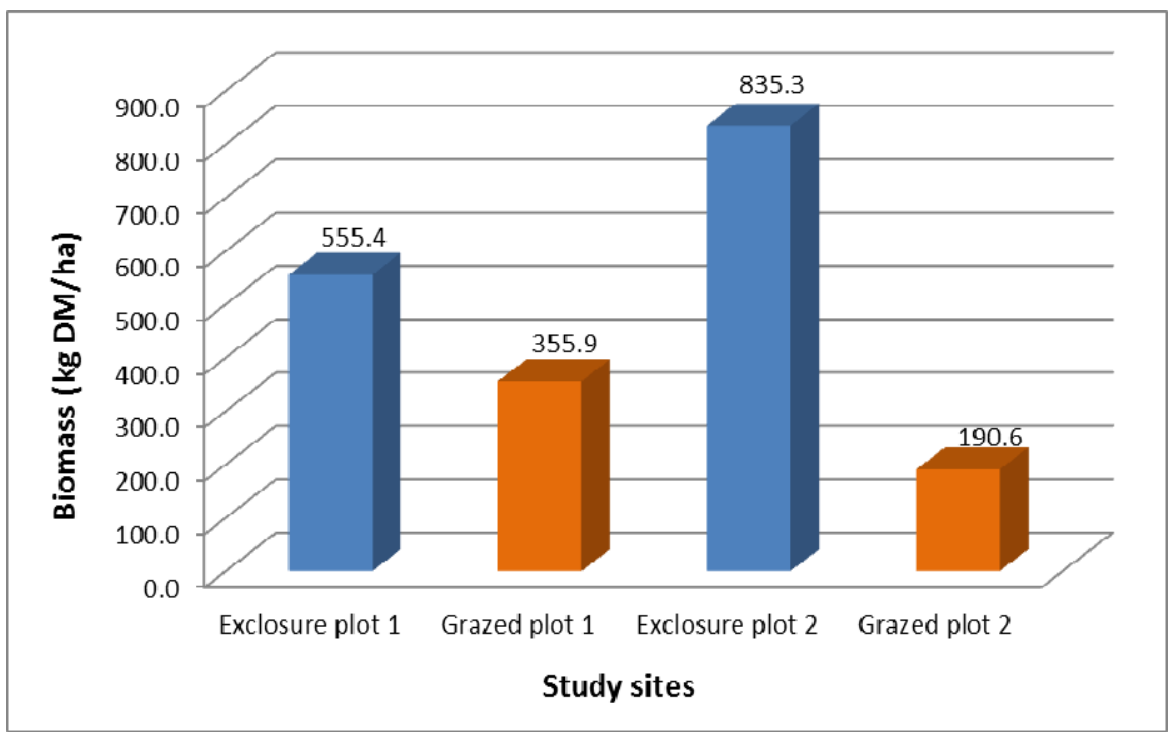

Fig. 5. Biomass of the Koti-Sephola peatland in Lesotho. 
number of 24 different species were identified comprising $13 \%$ grasses and $87 \%$ forbs. The canopy cover of the wetland ranged between $65 \%$ and $100 \%$ with medium sized erosion dongas present.

Biomass for the exclosure plots was $555.4 \mathrm{~kg} \mathrm{DM} / \mathrm{ha}$ and $835.3 \mathrm{~kg} \mathrm{DM} /$ ha respectively compared to the low $355.9 \mathrm{~kg} \mathrm{DM} / \mathrm{ha}$ and $190.6 \mathrm{~kg} \mathrm{DM} /$ ha for grazed plots 3.2 and 4.2 (Figure 5). There was no difference in species composition between the exclosure and grazed plots (Table 1). The average height of the herbaceous layer was $3.8 \mathrm{~cm}$ compared to $1.8 \mathrm{~cm}$ in the grazed plots.

\subsection{Kao}

The Kao peatland is characterized by the dominance of the forbs Cotula radicalis, Isolepis cernua, and Haplocarpa nervosa (Plots 16-18, Species group B - Table 1). A total number of 21 different species were identified comprising $14 \%$ grasses and $86 \%$ forbs. The canopy cover of the wetland ranged between $60 \%$ and $90 \%$ with medium to sized erosion dongas present.

Biomass was low at $185.4 \mathrm{~kg} \mathrm{DM} / \mathrm{ha}$ and $145.5 \mathrm{~kg} \mathrm{DM} /$ ha with the herbaceous layer only $1.5 \mathrm{~cm}$ high.

\subsection{Platberg peatlands}

The Platberg peatlands are characterised by the dominance of the grasses Andropogon appendiculatus and Pennisetum sphacelata while the grass Pentaschistis species and the sedge Ficinia stolonifera are prominent locally (Plots 1-7, Species group A - Table 1). A total of 19 different plant species comprising $42 \%$ grasses and $58 \%$ forbs were present. Canopy cover ranged between $75 \%$ and $100 \%$ with no signs of erosion observed.

These wetlands had an average biomass of $4302.5 \mathrm{~kg}$ DM/ha ranging between $2555.1 \mathrm{~kg}$ $\mathrm{DM} / \mathrm{ha}$ and $5954.4 \mathrm{~kg} \mathrm{DM} /$ ha (Figure 6). An average height of $51 \mathrm{~cm}$ was measured for the herbaceous layer.

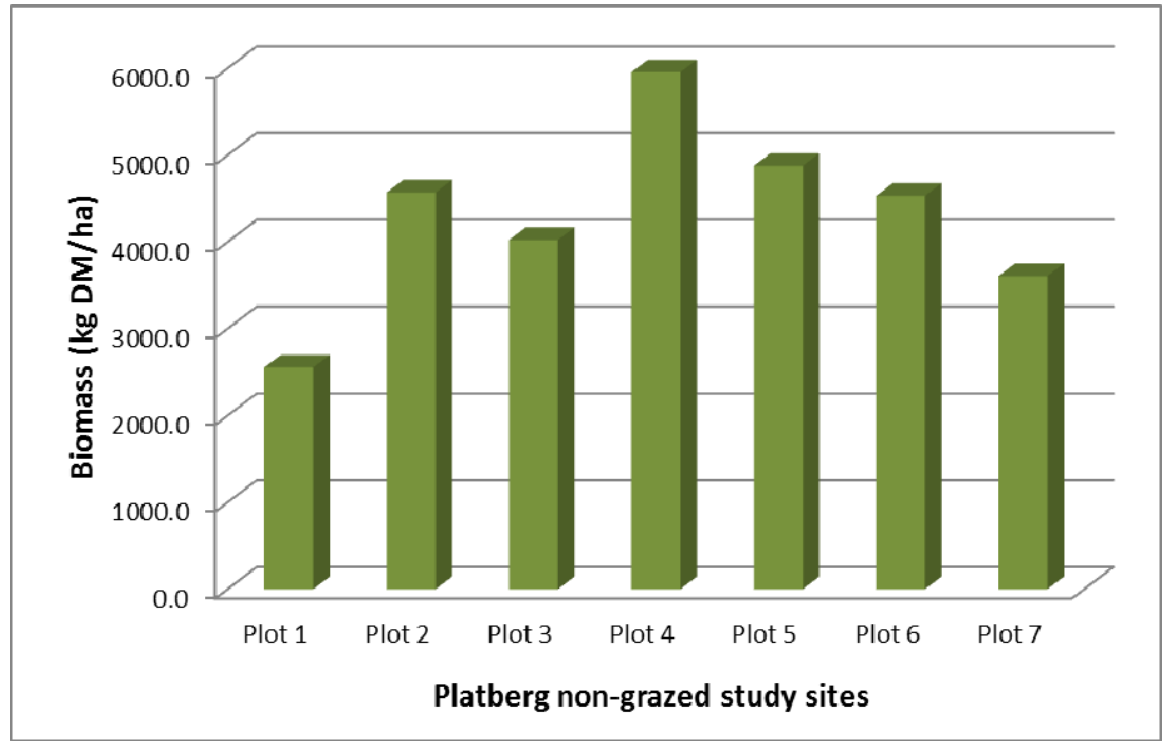

Fig. 6. Biomass of the Platberg peatlands in South Africa. 


\subsection{Biomass per grazing type}

The following boxplot uses the medians and quartiles to compare the distributions of biomass (kg DM/ha) of the plots by grazing type (non-grazed; exclosure plots; grazed) (Figure 7).

As expected there is some overlap in the values of the grazed and exclosure plots, the latter only being fenced off for the past 12 months, while the non-grazed plots have some overlap with the exclosure plots. Thus although there appear to be differences between the grazed and exclosure plots the overlap results in there being a non-significant difference between them.

Although overlaps exist, differences between the different treatments are observed indicating that the non-grazed Platberg peatlands have the highest production followed by the exclosure plots that show variable increases within the short time (12 months) since being fenced off, compared to the open grazed plots.

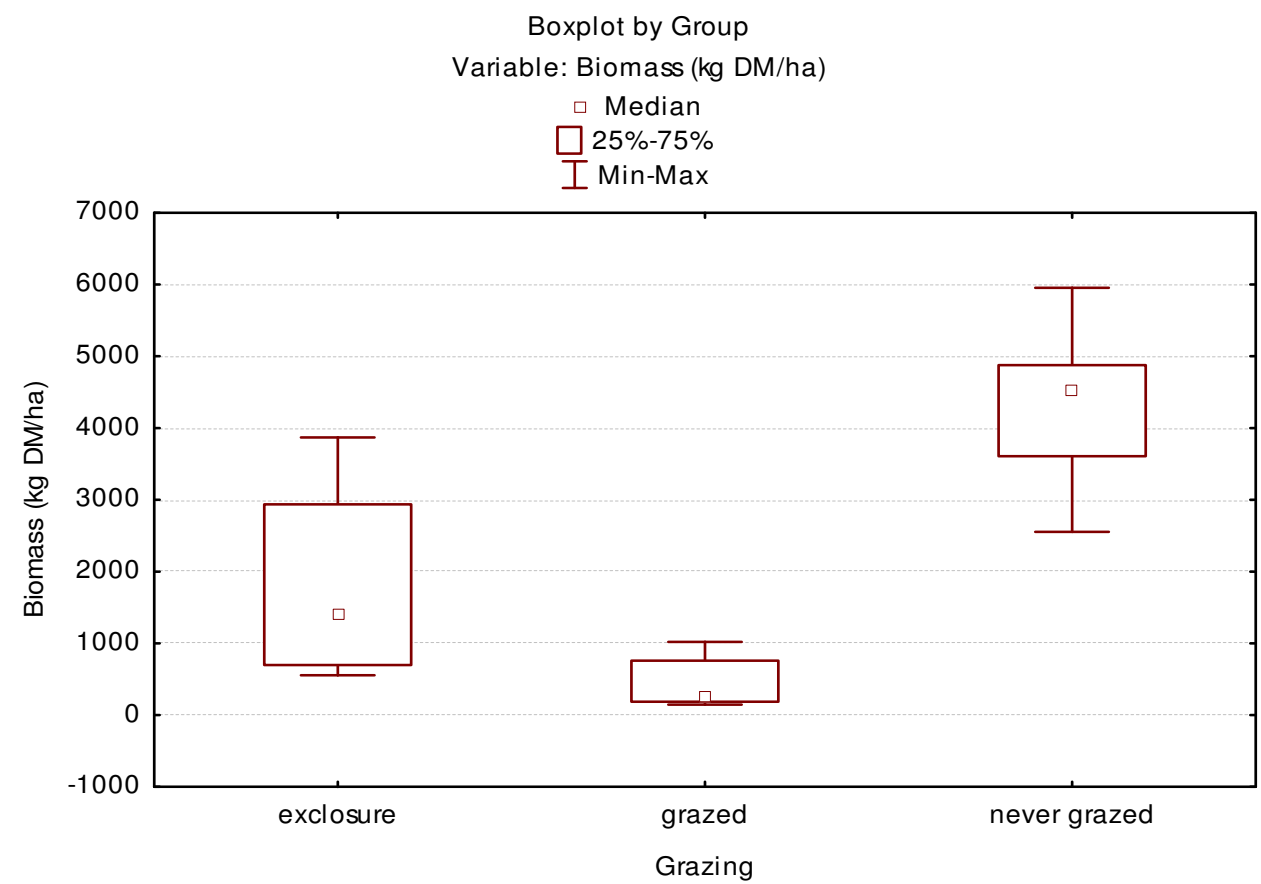

Fig. 7. Boxplots of the medians and quartiles comparing the biomass of the different grazing types.

The Kruskal-Wallis ANOVA by Ranks test was used to compare the Biomass (kg DM/ha) of the plots by grazing type. From the Kruskal-Wallis test $[\mathrm{H}(2, \mathrm{~N}=17)=12.071 \mathrm{p}=.0024]$ it shows that there is a significant difference in the ranks of the plots categorised by grazing type (Table 2). Significant differences were found between the grazed, non-grazed and exclosure plots. By using the the Mann-Whitney U Test on the ranked data the significant differences were found to be between the grazed and non-grazed plots $(p<0.01)$ and 
between exclosure and non-grazed plots $(\mathrm{p}<0.05)$. The Platberg peatlands with no grazing present therefore significantly differs in terms of production from both the grazed and exclosure plots with a much higher biomass as a result of the absence of grazers.

\begin{tabular}{|c|c|c|c|}
\cline { 2 - 4 } \multicolumn{1}{c|}{} & Code & $\begin{array}{c}\text { Valid - } \\
\text { N }\end{array}$ & $\begin{array}{c}\text { Sum of - } \\
\text { Ranks }\end{array}$ \\
\hline Exclosure plots & 101 & 4 & 33 \\
\hline Grazed plots & 102 & 6 & 24 \\
\hline Non- grazed plots & 103 & 7 & 96 \\
\hline
\end{tabular}

Table 2. Kruskal-Wallis ANOVA by Ranks; Biomass Independent (grouping) variable: Grazing Kruskal-Wallis test: $\mathrm{H}$ ( 2, N=17)

\section{Discussion}

\subsection{Species composition and richness}

Two distinctive vegetation communities resulted from the data classification namely the Platberg and Lesotho peatlands respectively (Table 1). Each unit reflects the homogeneity of the communities in terms of plant species composition and dominance. In all wetlands the forbs (including geophytes, succulents and sedges) comprised the largest percentage of species with grasses the lowest. The uniqueness of each unit can be ascribed to various physical factors such as altitude, $\mathrm{pH}$, moisture regime of the peat, and biotic impact.

Studies done by Sieben et al. (2010) revealed that typical wetland plants cannot cope well with the cold conditions during winter months. This opens several niches for forbs, especially species that are not dominant in lowland wetlands to become dominant in high altitude wetlands. The forb Ranunculus meyeri (Species group B - Table 1) is such a species, which occur across all altitudes but are dominant in high-altitude wetlands (Sieben et al., 2010). This species was found to be prominent in the Lesotho peatlands.

The peat deposits vary in depth from shallow $10 \mathrm{~cm}$ to over $2 \mathrm{~m}$ deep (Kuenene, 2008). The peatlands are covered by short mat-like peat forming plants. Dominant species in the Lesotho peatlands include the grass Pentaschistis oreodoxa, the sedge Isolepis cernua, the geophyte Rhodohypoxis deflexa, and the forbs Haplocarpa nervosa, Cotuls radicalis and Ranunculus meyeri (Table 1). Unlike the Lesotho peatlands, the platberg peatlands are mainly grassland dominated with the grasses Andropogon appendiculautus and Pennisetum sphacelatum prominent. The sedge Ficinia stolonifera and the grass Helictotrichon longifolium are locally dominant (Table 1).

Waterlogged conditions are a requirement for peat formation. Peat formation is a very slow process and is mainly formed from the root decay of vascular plants that grow on the peatlands. This process takes place in the absence of oxygen. Anoxia or reduction conditions between and below the roots, decomposes the dead material to form amorphous peat. According to the species composition of the wetlands at Khalong-la-Lithunya, Koti-Sepola, and Kao, sedges such as Isolepis cernua are together with forbs such as Haplocarpha nervosa, and Ranunculus meyeri the main contributors to peat formation. In contrast at Platberg the grasses Andropogon appendiculatus, Pennisetum sphacelatum and Helictotrichon longifolium are the main contributors to peat formation. 
A characteristic of these peatlands is the frost-induced mounds or thufur (Figure 8). Backéus \& Grab (1995) and Grab (1994) investigated these thufur and concluded that their morphological changes can be correlated to the changing environmental state of the peatlands. These thufur are present on hill slope seeps and valley head fens. The species composition of these thufur differs from the surrounding wetland vegetation and can be attributed to a relatively lower moisture content. Species that dominate the thufur at the study sites are Helichrysum bellidiastrum, Athrixia fontana, and Sebaea marlothii.



Fig. 8. Frost-induced mounds or thufur (mounds), with a different species composition (insert) present on the peatlands.

Another characteristic of these peatlands are the open water pools or tarns. The typical vegetation is floating-leaved and submergent aquatic vegetation. Dominant species present in these open water bodies are the grass Colpodium drakensbergensis, the forbs Crassula natans, Lagarosiphon muscoides, and Limosella maior were found at Khalong-la-Lithunya, Kao and Koti-Sephola.

The catchment slopes are characterised by shallow soils and a relatively high percentage of surface rock. The soil has a relatively low organic content due to the high runoff onto the peatlands that has resulted in degraded vegetation and coarse soil texture.

Extensive grazing depletes the root and canopy reserves of perennial grasses (Carpenter et al. 2001) which are then replaced by annual and other forb species. This will have a negative impact on the resilience of the system to maintain its ecosystem functions such as water storage, nutrient cycling and production. In the Lesotho peatlands the forbs comprise the largest percentage (86-87\%) of the species composition, while in the Platberg peatlands there is a more even species composition ( $42 \%$ grasses and $58 \%$ forbs). Thus, it 
seems as though the long-term grazing of these systems has affected the species composition. The average species richness for the Platberg peatlands (11.4) is lower than the Lesotho peatlands (17.5). The higher richness in the Lesotho peatlands can be ascribed to greater habitat diversity as a result of various environmental factors resulting in the formation of peat and thurfur on the peatland surface as well as its short structure. In contrast the dense and tall grass tufts of the Platberg peatlands have a shading effect on the lower stratum of the herbaceous layer. This could prevent various forb species from establishing that could explain the lower species richness found. Brown \& Bugg (2001) also found that established perennial grasses inhibited the growth of seeded forbs. There are also no thurfur present within the Platberg peatlands with its more homogeneous habitat.

\subsection{Effects of grazing on biomass}

It is generally believed that overgrazing is one of the most important factors causing vegetation degradation (Danckwerts \& Tainton, 1996; David et al., 2000). Furthermore it could influence the hydrological status, stability and productivity of the ecosystem (Kirkman \& Moore, 1995; O'Connor \& Bredenkamp, 1997; Snyman \& Fouché, 1991; Snyman 1997, 1998). Biomass is a good indicator of available forage and the risk of soil erosion (Schino et al., 2003). Biomass is dependent on the root reserves, nutrient and water content of the soil. Overgrazing can negatively affect the species composition and especially biomass production leading to a decrease in resilience of the ecosystem (Carpenter et al., 2001). This is evident from the results of this study where a significant difference was found between the production of the non-grazed Platberg peatlands compared to the grazed and exclosure plots in Lesotho indicating the negative effect of long-term grazing on these peatlands. The grasses in the recently erected exclosures (12 months ago) of the Lesotho peatlands show an increase in production compared to the grazed plots with some overlap with the non-grazed plots of Platberg (Figures 3, 4 \& 6). Although not statistically significant at this stage the exclosure plots appear to have a higher production and it is expected that the difference may only become significant with a larger sample size and with continued monitoring over a longer term. This also correlates with the lower height levels of the plants in these plots compared to the exclosure plots. Structurally the Platberg peatlands are much taller with an average height of $51 \mathrm{~cm}$ compared to the short Lesotho peatlands with and average height ranging between 1.5 and $6 \mathrm{~cm}$. The near pristine peatlands of Platberg had on average a much higher production and canopy cover with no signs of erosion. The exclosure plots of the Khalong-la-Lithunya peatland had similar biomass values than the Platberg peatlands indicating that if grazing is decreased production will increase.

The grasses in the exclosure plots showed a higher production $(598.6 \mathrm{~kg} \mathrm{DM} / \mathrm{ha}-8 \%$ of total biomass) than the grasses in the grazed plots ( $68.6 \mathrm{~kg} \mathrm{DM} / \mathrm{ha}-2.6 \%$ of total biomass). It therefore appears that where grazing is absent that the grasses could become more prominent exerting a greater influence on the vegetation thereby causing a future change in species composition.

The Platberg peatlands have a higher amount of energy stored (due to the higher biomass) than the degraded Lesotho peatlands also meaning that it has a higher carbon storage ecosystem functioning. 


\subsection{Other effects of grazing}

Grazing of these peatlands by domestic stock (wild horses, cattle, donkeys, goats and sheep) causes trampling of the vegetation that can result in footpaths (Figure 9) and deep hoof prints in the peatlands. These impacted areas can quicly become devoid of vegetation.

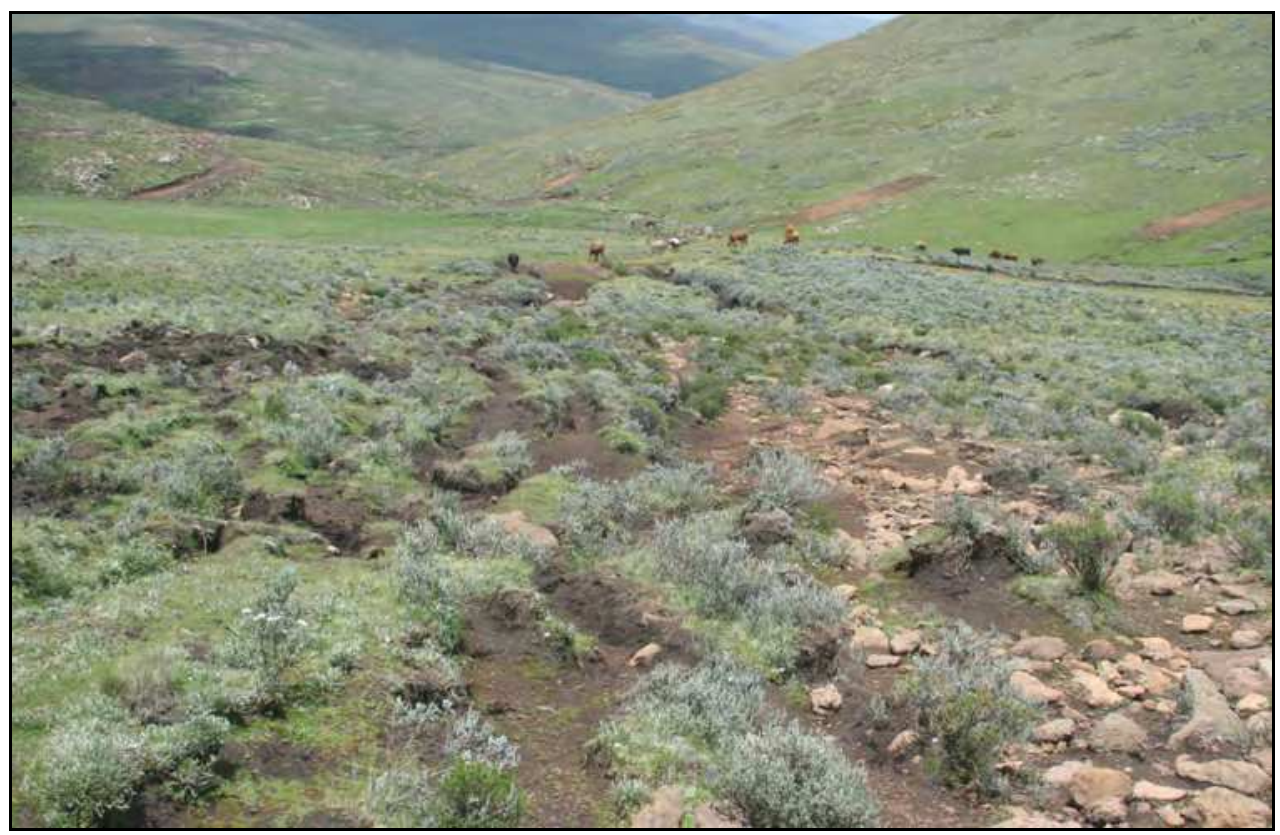

Fig. 9. Footpaths, devoid of vegetation, leading to the formation of erosion gullies in the peatlands as a result of trampling by domestic stock.

However, the heavy animals such as horses and cattle trample holes into the vegetation (Figure 10). These hoof prints form larger holes which eventually start to erode. The

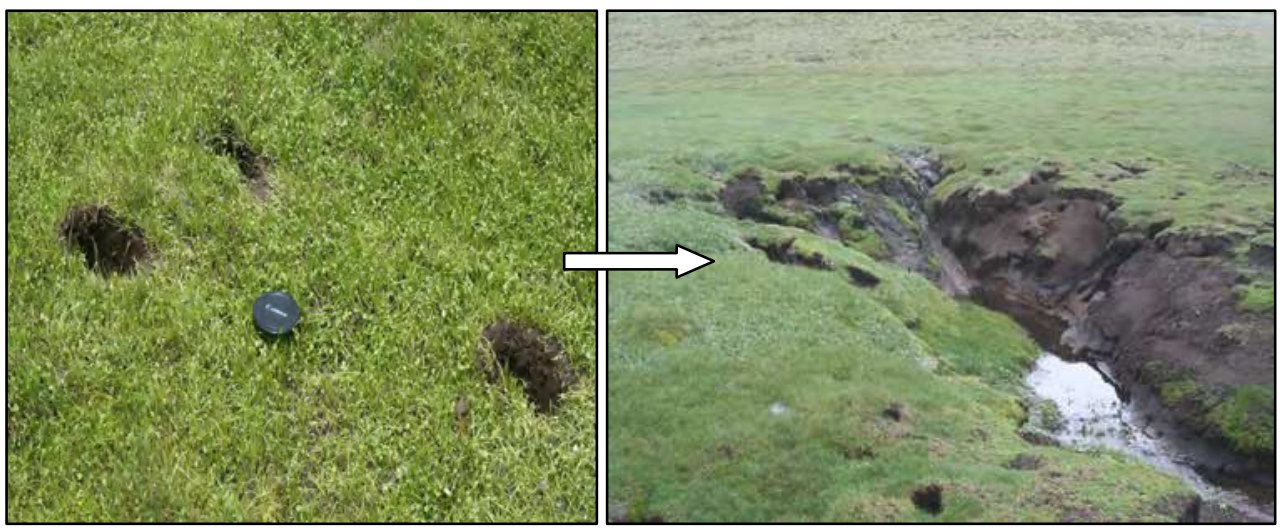

Fig. 10. Deep hoof imprints of animals into the peatlands causing erosion in the long term 
vegetation also dies off due to the high urea-content of the urine of animals (Figure 11), while cow dung covers the vegetation for a significant period of time causing the exclusion of sunlight, which put the affected plants under stress leading to die off of the vegetation with other species establishing (Figure 12).

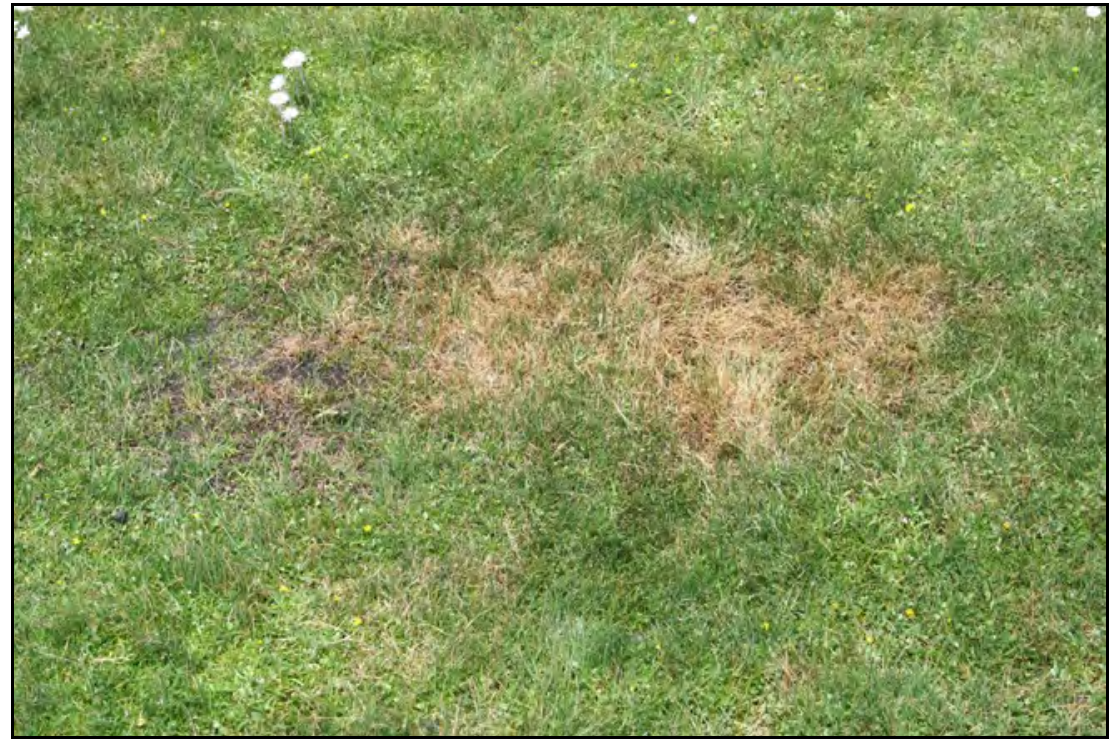

Fig. 11. Vegetation die-off caused by the high urea content of the urine of domestic stock grazing on the peatlands.

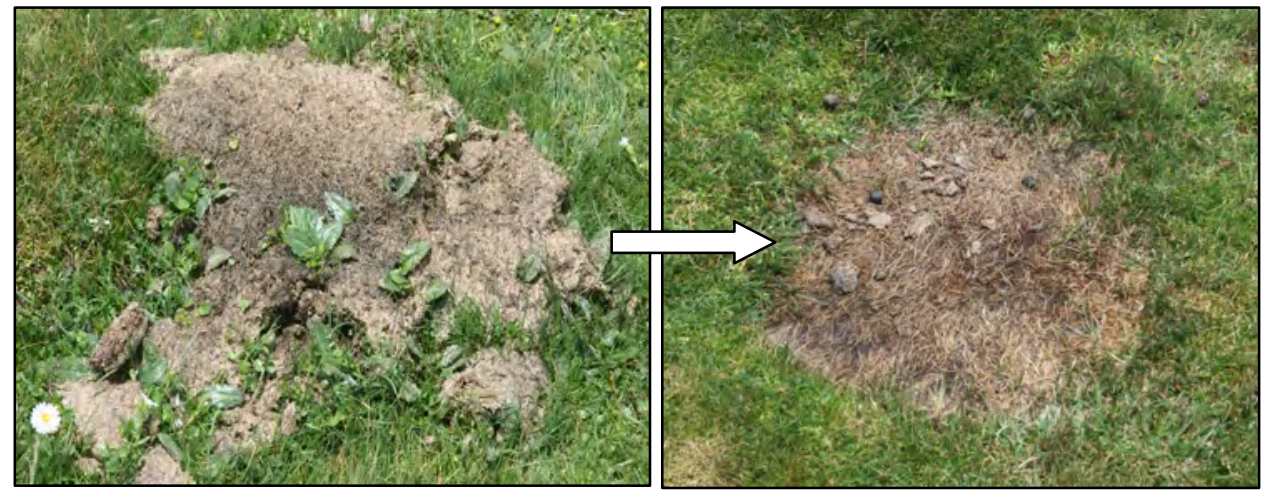

Fig. 12. Cow dung covers the vegetation for a significant period of time also leading to vegetation die-off with other species establishing.

Footpaths (Figure 9) are another major contributor to wetland degradation. On footpaths the animal hooves usually cause destruction of the vegetation cover which in turn results in the formation of large erosion gullies. 
Due to the formation of erosion gullies, lateral drainage from the peat takes place at an alarming rate. Desiccation of the peat takes place along the gully which allows the peat to dry out and becomes eroded. A contributing factor is the trampling of the gully banks as animals drink from the streams. Their hooves loosen the dry peat which drains down to the streams (Figure 13).

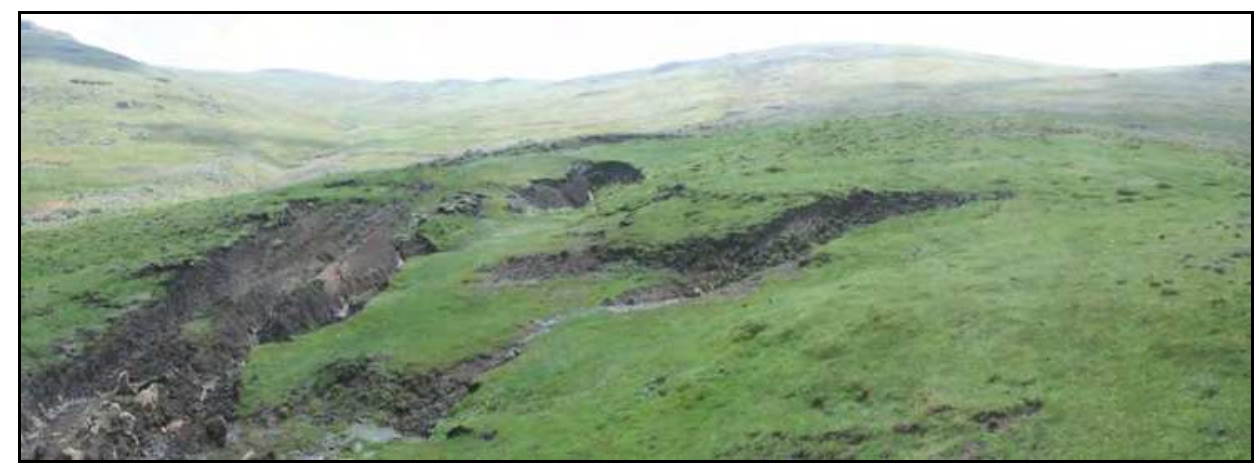

Fig. 13. Large erosion gullies in the peatlands as a result of trampling and overgrazing.

The ice rat (Otomys sloggettii) (Figure 14) is a natural inhabitant of high-altitude vegetation types including peatlands (Schwaibold, 2005). On an undisturbed peatland these rats' dens, runways and tunnels are limited to the peatland fringes and drier areas. The desiccation of the peatlands results in the encroachment of these rodents onto the drier parts, especially around those areas near erosion gullies. Their tunnels contribute to the erosion and agrivating the desiccation the peat (Figure 13) as well as the alteration of the habitat conditions. This leads to various terrestrial plant species establishing thereby displacing the peatland vegetation.

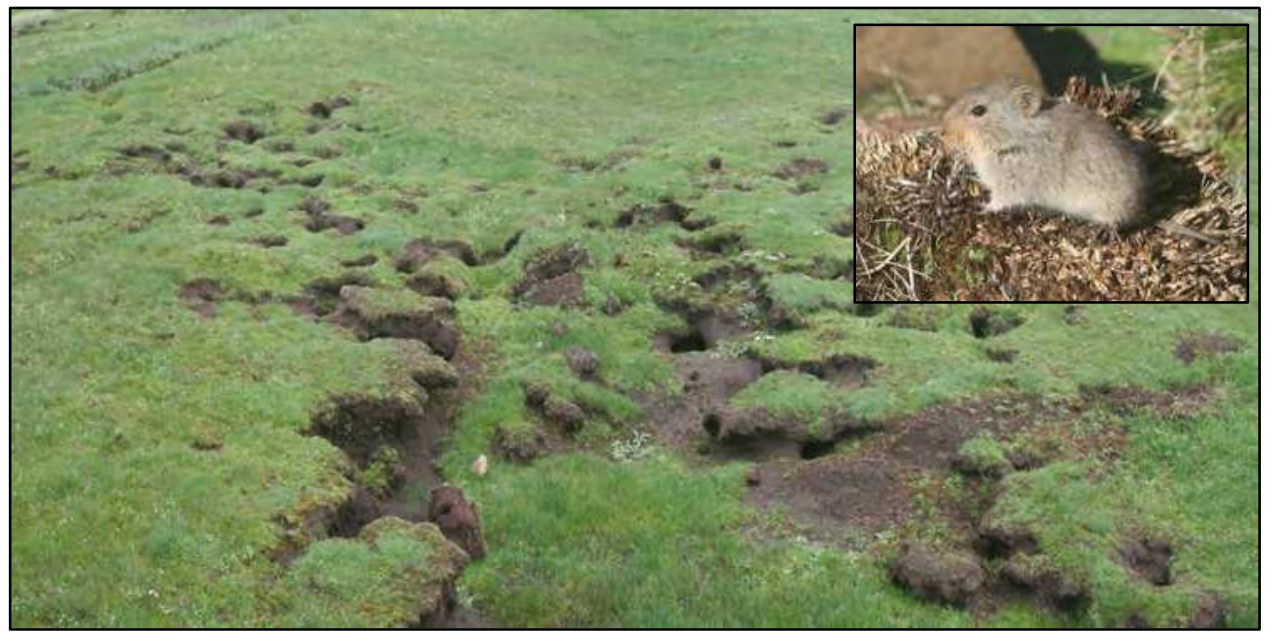

Fig. 14. The ice rat (Otomys sloggettii) (insert) with its tunnels draining the peatlands and causing erosion. 


\section{Conclusion}

Due to the low vegetation cover, shallow soils and steep slopes of the valley heads in Lesotho, there is a high water and sediment run off (Figure 15). The peatlands are the only sites where water is being retained and slowly released. These peatlands are very valuable socioecological ecosystems to the highlands of Lesotho because of the goods and services they present. The natural vegetation of these peatlands sustains extensive grazing by domestic livestock. Destruction of these peatlands will have serious implications for the ecosystems and biodiversity of the region. The high runoff sometimes results in the deposition of sediment onto the peatlands. In these instances a sedimentation fan forms on top of the peatland. Subsequently the covered wetland vegetation dies off.

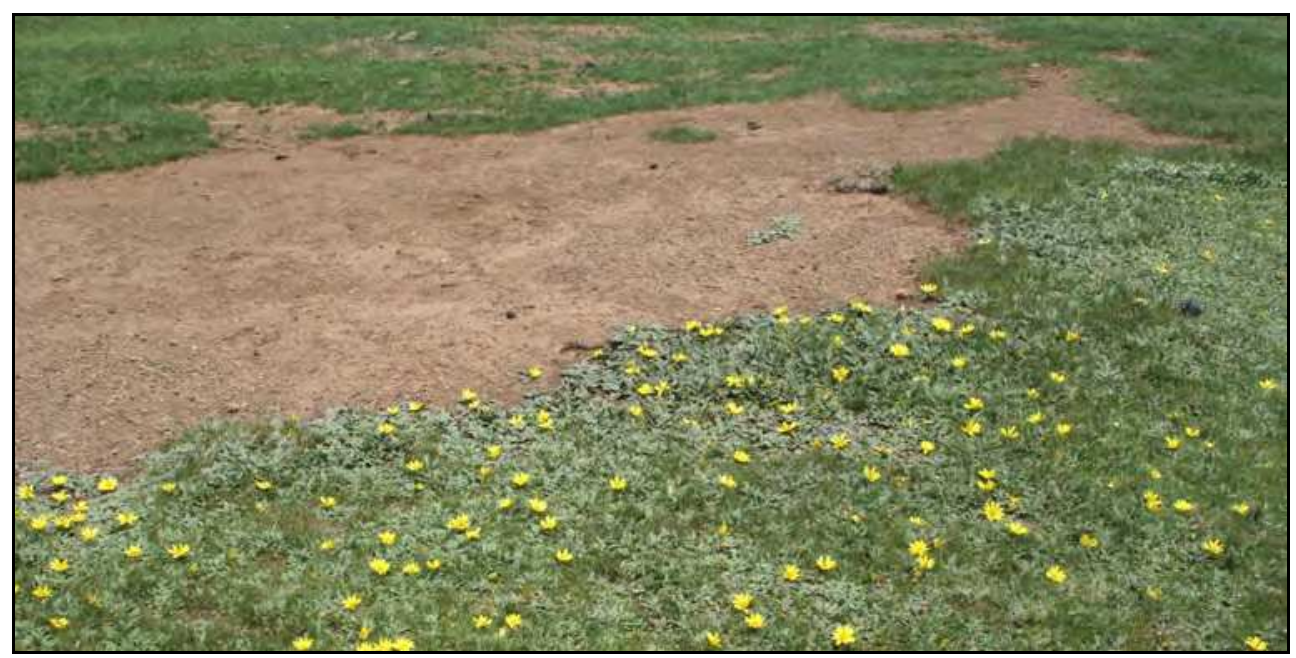

Fig. 15. Sediment runoff from the surrounding catchment areas onto the peatlands.

All the Lesotho peatlands as well as the surrounding upland slopes are heavily affected by grazing and trampling. Species composition of the slopes has been affected significantly. These slopes are all dominated by unpalatable dwarf shrubs such as Helichrysum trilineatum, Eumorphia sericea, Chrysocoma ciliata, Euryops decurrens and the absence of grass species is notable.

The degradation of these peatlands cannot really be attributed to the grazing per se of the wetland species. It has been noted that these mat forming plants especially Isolepis cernua has a remarkable tolerance of heavy grazing and the peatlands still maintain high species richness. A very dense cover remains despite the heavy grazing pressure.

The canopy cover of the herbaceous plants of both the Lesotho and near pristine Platberg peatland systems was generally high though the latter had a taller and more diverse structure. The more pristine Platberg peatlands had a lower species richness with a larger grass component than the Lesotho peatland areas. Furthermore the Platberg peatlands had a markedly higher biomass production than the Lesotho peatlands. However the exclosure plots showed a noticible increase in production compared to the grazed plots indicating the resilience of these systems if properly managed. 
The resilience of a system is dependant on its ability to sustain nutrient cycles and the storage of water. This ability is threatened when degradation of the habitat occurs via soil loss and structural change of the vegetation (Carpenter et al., 2001). Based on the results from this study it is clear that structural changes and soil loss have taken place in the Lesotho high-altitude peatlands (Figure 16) accompanied by a lower production. No improvements in the condition of the wetland and associated upland sites will be possible without a reduction in the grazing pressure in these areas. Degraded vegetation cover already leads to increased overland flow visible as gravel on the soil surface in the hill slopes and gully erosion in the wetlands. Reduced organic matter content in all the soils is expected due to drier soil conditions and short vegetation. Land use change will impact on soil hydrology and that impact will be reflected in the wetland hydrology.

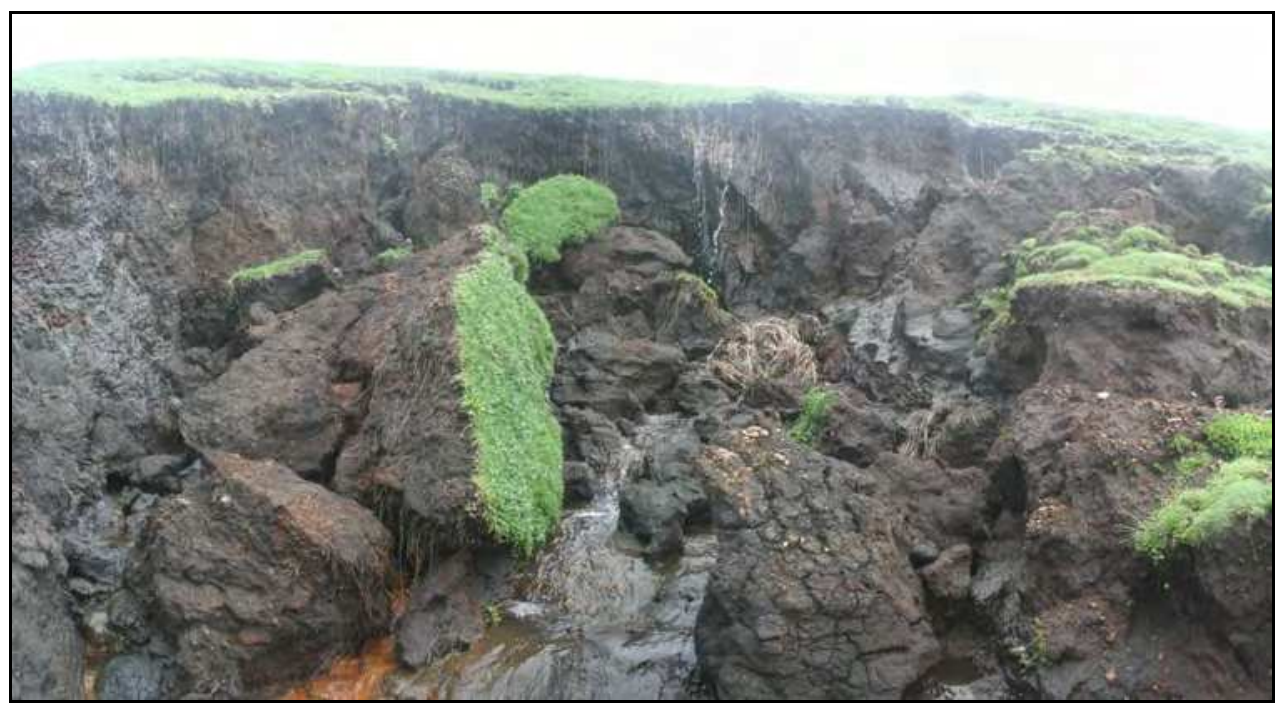

Fig. 16. Large scale erosion as a result of heavy grazing resulting in the degradation of the habitat and a loss of ecosystem functions.

In view of the uniqueness of these peatlands and the high endemicity of the Lesotho Highland Basalt Grassland vegetation it is urgent to identify and proclaim more wildlife conservation areas within the Lesotho highlands. As mentioned above a large transfrontier park namely the Maloti-Transfrontier Park is planned to protect the high-altitude vegetation of Lesotho and South Africa. Mucina \& Rutherford (2006) state that this proposed park would increase the conservation status of Lesotho Highland Basalt Grassland. However, the authors of this chapter have their doubts about the effectiveness of such a Transfrontier Park to protect sensitive ecosystems such as peatlands. The reason being that with the proclamation of such as Transfrontier Park the landuse within the transfrontier park would not change significantly.

The authors are therefore proposing smaller conservation areas within the larger Transfrontier Park, which would exclude domestic animals, specifically to protect the peatlands and their catchments. These conservation areas would not only properly protect 
peatlands, but would also protect the indigenous wildlife populations of grey rheebuck, rock hyrax, and several other species, which are on the brink of extinction in Lesotho. Long term monitoring of the exclosure and grazed plots should be continued on these sensitive ecosystems to provide a basis for decision making.

\section{References}

Backéus, I. \& Grab, S. 1995. Mires in Lesotho. Gunneria 70:243-250. ISSN.0332-8554

Brown, C. S. \& Bugg, R. L. (2001), Effects of Established Perennial Grasses on Introduction of Native Forbs in California. Restoration Ecology, Vol.9, pp. 38-48, doi: 10.1046/j.1526100x.2001.009001038.x

Brown, L.R., Marais, H., Henzi, S.P. and Barrett, L. (2005). Vegetation classification as the basis for baboon management in the Bourke's Luck Section of the Blyde Canyon Nature Reserve, Mpumalanga. Koedoe, Vol.48, Number2, pp. 71-92, ISSN 0075-6485.

Carpenter, S., Walker, B., Anderies, J.M., \& Abel, N. (2001). From Metaphor to Measurement:Resilience of What to What? Ecosystems Vol.4, pp. 765-781. DOI: 10.1007/s10021-001-0045-9.

Cleaver G. (2004). Environmental impacts of large-scale groundwater abstraction on ecosystems of the Kammanassie Mountain. M.Tech Dissertaion, University of South Africa, Pretoria.

Collins, N.B. (2005). Wetlands: The basics and some more. Free State Department of Tourism, Environmental and Econimic Affairs. ISBN 0-86886-708-X, Bloemfontein.

Cowan,G I (ed.). (1995). Wetlands of South Africa. Department of Environmental Affairs and Tourism, ISBN 0-62116817-3, Pretoria.

Cronk, J.K. \& Fennessey, M.S. (2001). Wetland plants: biology and ecology. Lewis Publishers, ISBN 978-0-415-55426-8, Boca Raton.

Danckwerts, J.E. \& Tainton, N.M. (1996). Range management. Optimization of forage production and quality. Bulletin of the Grassland Society of Southern Africa, Vol.7, pp. 36-42, ISSN 101-66122.

David, W., Ngairorue, B.T., Apollus, A. \& Tjieveze, H. (2000). Perceptions and realities of land degradation in arid Otjimbingwe, Nambia. Journal of Arid Environments, Vol.45, pp. 337-356, ISSN 0140-1963.

De Leeuw, P.N., Grandin, B.E. \& Solomon, B. (1991). Introduction to the Kenyan rangelands and Kajiado District. In: Maasai herding: An analysis of the livestock production system of Maasai pastoralists in eastern Kajiado District, Kenya. Solomon, B., De Leeuw, P.N., Grandin, B.E. \& Neate, P.J.H. (Eds.) International Livestock Center for Africa (ILCA), ISBN 92-9053-176-2, Ethiopia.

Du Preez, P.J. (1991). A syntaxonomical and synecological study of the vegetation of the southern and eastern Orange Free State and related areas with special reference to Korannaberg. Ph.D. thesis, Dept of Botany, UFS. Bloemfontein.

Grab, S.W. (1994). Thufur in the Mohlesi valley, Lesotho, southern Africa. Permafrost and periglacial processes, Vol. 5, pp. 111-118, ISSN.1099-1530.

Grobbelaar, J.U. \& Stegman P. (1987). Limnological characteristics, water quality and conservation measures of a high altitude bog and rivers in the Maluti mountains, Lesotho. Water South Africa. Vol. 13, pp. 151-158, ISSN 0378-4738. 
Herbst, S.N. \& Roberts, B.R. (1974a). Quantitative ecological relationships in the Alpine grassland of Lesotho. Proceedings of the Grassland Society of South Africa, Vol. 9, pp. 61-66, ISSN.1551-5028.

Herbst, S.N. \& Roberts, B.R. (1974b). The Alpine vegetation of the Lesotho Drakensberg: a study in quantitative floristics at Oxbow. Journal of South African Botany, Vol. 40, pp. 257-267, ISSN 0254-6299.

Hennekens, S.M. \& Schaminée, J.H.J. 2001. TURBOVEG, a comprehensive database management system for vegetation data. Journal of Vegetation Science 12: 589-591 ISSN.1100-9233

Hill, M.O. (1979). TWINSPAN: A FORTRAN program for arranging multivariate data in an ordered two-way table by classification of the individuals and attributes. Cornell University, Ithaca.

Jacot Guillarmod, A. (1962). Bogs and sponges of Basutoland mountains. Journal of South African Botany, Vol. 58, pp. 179-182, ISSN 0254-6299.

Jacot Guillarmod, A. (1963). Further observations on bogs of Basutoland mountains. Journal of South African Science, Vol. 59, pp. 115-118, ISSN 0038-2353.

Jacot Guillarmod, A. (1972). Bogs and sponges of the Orange River catchment within Lesotho. Civ. Engr S. Afr. Vol. 14, pp. 84-85, ISSN. 0305-1 315 .

Kirkman, K.P. \& Moore, A. (1995). Towards improved grazing management recommendations for sourveld. African Journal of Range and Forage Science. Vol. 12, No. 3, pp. 135-144, ISSN 1022-0119.

Kotze DC, (1999). A system for supporting wetland management decisions. Ph.D. thesis. School of Applied Environmental Sciences, University of Natal, Pietermaritzburg.

Kotze, D.C. 2010. WET-Sustainable-USE. A system for assessing sustainability of wetland use. WRC report. WRC Report no TT 438/09

Kotze, D.C., Marnewick,G., Batchelor, A., Lindley, D. \& Collins, N.B. 2008. WET-EcoServices. A technique for rapidly assessing ecosystem services supplied by wetlands. WRC report TT339/8, Pretoria.

Kuenene, B.T. (2008). Soil morphology as signature of soil hydrology in selected catchments. M.Sc. dissertation. University of Free State, Bloemfontein, South Africa.

Letsela, T., Balkwill, K. \& Witkowksi, E.T.F. (2002). Conservation and sustainable livelihoods in Bokong and Tsehlanyane in Lesotho. In: Contested resources: challenges to governance of natural resources in southern Africa, T.A. Benjamin, B. Cousins \& L. Thomson (Eds.), 192-200. University of the Western Cape, Programs for land and agrarian studies, ISBN 1-86808-537-6, South Africa.

Lubomír, T. (2002). JUICE, software for vegetation classification. Journal of Vegetation Science Vol.13, pp. 451-453, ISSN 1100-9233

Malan, P.W. (1998). Vegetation ecology of the Southern Free State. Unpublished PhD thesis, University of the Orange Free State, Bloemfontein.

Mitch, W.J \& Gosselink, J.G. (2000). Wetlands,(3rd edition). Van Nostrand Reinhold, ISBN 0471-29232-x, New York.

Mpiti-Shakhane, L.M., Kanyama-Phiri, G.Y., Odenya, W.O. \& Banda, J.W. (2002). Sheep response to different stocking rates and seasonal variation under rangeland 
conditions of Lesotho. African Journal of Range and Forage Science, Vol.19, pp. 71-75, ISSN 1022-0119.

Mucina L. \& Rutherford M.C. (2006). The vegetation of South Africa, Lesotho and Swaziland. South African National Biodiversity Institute, ISBN 978-1-919976-21-1, South Africa.

Mueller-Dombois, D. and Ellenberg, H. (1974). Aims and methods of vegetation ecology. J. Wiley \& Sons, ISBN 04-1622907, New York.

O`Connor, T.G. \& Bredenkamp, G.J. (1997). Grassland. In: Vegetation of Southern Africa, Cowling, R.M., Richardson, D.M. \& Pierce, S.M. (Eds.), 215-257, Cambridge University Press, ISBN 0-521-57142-1, Cambridge.

Pieper, R.D. (1978). Measurement techniques for herbaceous and shrubby vegetation. Mimeograph Series, ISBN 0817639659, New Mexico State University, Las Cruces.

Schino G, Borfecchia F, De Cecco L, Camilla Dibari C, Iannetta M, Sandro Martini S and Franco Pedrott F. (2003). Satellite estimate of grass biomass in a mountainous range in central Italy. Agroforestry Systems 59 (2): 157-162, DOI: 10.1023/A:1026308928874

Schmitz, G. \& Rooyani, F. (1987). Lesotho geology, geomorphology, soils. Morija Printing Works, ISBN 354029144X, The National University of Lesotho, Lesotho.

Schwaibold, U.H. (2005). Foraging biology and habitat use of the southern African ice rat Otomys sloggettii robertsii. Unpublished Ph.D. dissertation. University of the Witwatersrand, Johannesburg

Sieben, E.J.J. \& Morris, E.D., C.D., Kotze, D.C \& Muasya, A.M. (2010). Changes in plant form and function across altitudinal and wetness gradients in the wetlands of the MalotiDrakensberg, South Africa. Plant Ecology, Vol.207, pp.107-139, ISSN 1573-5052.

Snyman, H.A. (1997). The influence of range condition on the hydrological characteristics in semi-arid rangelands. Proceedings of the XVIII International Grassland congress, Canada, Vol.2, No.23, pp. 1-2.

Snyman, H.A. (1998). Dynamics and sustainable utilisation of rangeland ecosystems in arid and semi-arid climates of Southern Africa. Journal of Arid Environments, Vol.39, pp. 645-666, ISSN 0140-1963.

Snyman, H.A. \& Fouche, H.J. (1991). Production and water-use efficiency of semiarid grasslands of South Africa as affected by veld condition and rainfall. Water South Africa, Vol17, pp.263-268, ISSN 0378-4738.

Snyman, H.A. \& Fouche, H.J. (1993). Estimating seasonal herbage production of a semi-arid grassland based on veld condition, rainfall and evapotranspiration. African Journal of Range and Forage Science, Vol.10, No.1, pp. 21-24, ISSN 1022-0119.

Van Zinderen Bakker, E.M, (1955). A preliminary survey of peat bogs of the alpine belt of northern Basutoland. Acta Geographica. Vol.14, pp. 413-422.

Van Zinderen Bakker, E.M. \& Werger, M.J.A. (1974). Environmental, vegetation and phytogeography of the high-altitude bogs of Lesotho. Vegetatio, Vol.29, pp. 37-49,

Welman C, Kruger F \& Mitchell B. 2007. Research Methodology (3rd edition). Oxford University Press Southern Africa, ISBN 978-0-19-578901-0, Cape Town. 
Westhoff, V. and Van der Maarel, E. 1980. The Braun-Blanquet approach, In: Classification of Plant Communities. R.H. Whitaker, (Ed.), 287-378, Kluwer Academic Publisher, ISBN 906-193566-0, The Hague. 


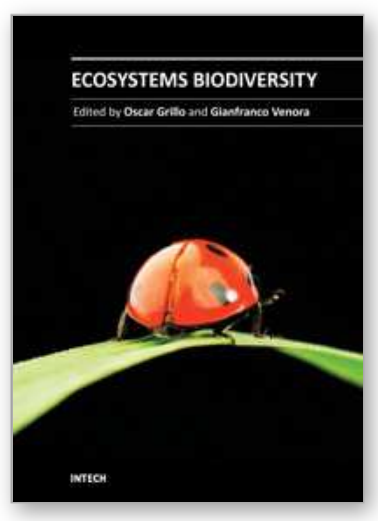

\author{
Ecosystems Biodiversity \\ Edited by PhD. Oscar Grillo
}

ISBN 978-953-307-417-7

Hard cover, 464 pages

Publisher InTech

Published online 16, December, 2011

Published in print edition December, 2011

Ecosystems can be considered as dynamic and interactive clusters made up of plants, animals and microorganism communities. Inevitably, mankind is an integral part of each ecosystem and as such enjoys all its provided benefits. Driven by the increasing necessity to preserve the ecosystem productivity, several ecological studies have been conducted in the last few years, highlighting the current state in which our planet is, and focusing on future perspectives. This book contains comprehensive overviews and original studies focused on hazard analysis and evaluation of ecological variables affecting species diversity, richness and distribution, in order to identify the best management strategies to face and solve the conservation problems.

\title{
How to reference
}

In order to correctly reference this scholarly work, feel free to copy and paste the following:

P.J. Du Preez and L.R. Brown (2011). Impact of Domestic Animals on Ecosystem Integrity of Lesotho High Altitude Peatlands, Ecosystems Biodiversity, PhD. Oscar Grillo (Ed.), ISBN: 978-953-307-417-7, InTech, Available from: http://www.intechopen.com/books/ecosystems-biodiversity/impact-of-domestic-animals-onecosystem-integrity-of-lesotho-high-altitude-peatlands

\section{INTECH}

open science | open minds

\section{InTech Europe}

University Campus STeP Ri

Slavka Krautzeka 83/A

51000 Rijeka, Croatia

Phone: +385 (51) 770447

Fax: +385 (51) 686166

www.intechopen.com

\section{InTech China}

Unit 405, Office Block, Hotel Equatorial Shanghai

No.65, Yan An Road (West), Shanghai, 200040, China

中国上海市延安西路65号上海国际贵都大饭店办公楼405单元

Phone: +86-21-62489820

Fax: +86-21-62489821 
(C) 2011 The Author(s). Licensee IntechOpen. This is an open access article distributed under the terms of the Creative Commons Attribution 3.0 License, which permits unrestricted use, distribution, and reproduction in any medium, provided the original work is properly cited. 